\title{
Comparison of subjective symptoms of autologous serum and dexpanthenol gels after pterygium surgery
}

\section{Pterjium cerrahisi sonrası otolog serum ve dekspantenol jellerin subjektif semptomlarının karşılaştııılması}

\author{
Ugur Gurlevik $^{1 *}$ (D), Mehmet Citirik ${ }^{2}$ (D), Erdogan Yasar ${ }^{1}$ (D), Sevilay Karahan ${ }^{3}$ \\ ${ }^{1}$ Aksaray Training and Research Hospital/Eye Clinic, Aksaray, Turkey \\ 2 University of Health Sciences, Ankara Ulucanlar Eye Education and Research Hospital, Ankara, Turkey \\ ${ }^{3}$ Hacettepe University, Medical Faculty Biostatistics Department, Ankara, Turkey \\ * Corresponding author: Ugur Gurlevik E-mail: ugurlevik@hotmail.com ORCID: 0000-0003-2965-481X \\ Received: 10 August 2019 Accepted: 4 March 2020
}

\begin{abstract}
Purpose: The aim of this study was to investigate the effect of autologous serum and dexpanthenol gel on subjective symptoms after pterygium surgery.

Methods: An evaluation was made of patients who underwent the same technique of pterygium surgery between June 2017 and December 2017. Patients were divided into 2 groups with autologous serum used postoperatively in Group 1 (n: 18) and 5\% dexpanthenol gel in Group 2 (n: 12). Evaluation was made of both groups in respect of postoperative pain, stinging, irritation, redness and graft edema.

Results: There was no statistically significant difference between the groups in respect of pain, stinging and watering on the 1 st, $3 \mathrm{rd}$ and 7 th days. A statistically significant decrease in these complaints was observed on days 3 and 7 in the group using dexpanthenol. There was no statistically significant difference between the groups on days 1, 3 and 7in respect of redness and graft edema. In both groups, a statistically significant increase was determined in these findings on days 3 and 7 .

Conclusion: After pterygium surgery, many agents increase the comfort of patients. Autologous serum is the most reliable and most investigated agent. Dexpanthenolmay be an alternative to anterior segment surgery in respect of patient comfort and wound healing.
\end{abstract}

Keywords: dexpanthenol, pterygium, autologous serum, verbal pain scale

( 2020 by the authors; licensee MEDITAGEM Ltd., Turkey. This article is an open access article distributed under the terms and conditions of the Creative Commons Attribution License (http://creativecommons.org/licenses/by/4.0/). 


\section{ÖZ}

Amaç: Bu çalışmanın amacı, pterjiyum cerrahisi sonrası otolog serum ve dekspantenol jelin subjektif semptomlar üzerindeki etkisini araştırmaktır.

Metod: Haziran 2017 ve Aralık 2017 tarihleri arasında aynı cerrah tarafından yapılan pterjiyum cerrahisi uygulanan hastaların değerlendirilmesi yapıldı. Hastalar 2 gruba ayrıldı. Grup 1'de (n: 18) ameliyat sonrası otolog serum kullananlar ve grup 2'de (n: 12) \%5 dekspantenol jel kullanılar vardı. Her iki grupta da postoperatif ağrı, batma, tahriş, kızarıklık ve greft ödemi yönünden değerlendirme yapıldı.

Bulgular: Gruplar arasında 1., 3. ve 7. günlerde ağrı, batma ve tahriş açısından istatistiksel olarak anlamlı fark yoktu. Dekspantenol kullanan grupta 3 ve 7. günlerde 1. güne göre bu şikayetlerde istatistiksel olarak anlamlı bir azalma gözlendi. Gruplar arasında kızarıklık ve greft ödemi açısından 1., 3. ve 7. günlerde istatistiksel olarak anlamlı fark yoktu. Her iki grupta da, bu bulgularda 3. ve 7. günlerde 1. güne göre istatistiksel olarak anlamlı bir artış tespit edildi.

Sonuç: Pterjiyum cerrahisi sonrası birçok ajan hasta konforunu arttırmaktadır. Otolog serum en güvenilir ve en çok araştırılan ajandır. \%5 Dexpanthenol jel, hastanın konforu ve yara iyileşmesi açısından ön segment cerrahisine alternatif olabilir.

Anahtar kelimeler: dexpanthenol, pterygium, otolog serum, sözel ağrı ölçeği

\section{INTRODUCTION}

Pterygium is a bulging fibrovascular tissue, usually observed in nasal bulb conjunctiva which protrudes from the interpalpebral space of the triangular shape onto the cornea. Pterygium may cause burning, stinging, redness, watering, itching and reduction in visual acuity. In the etiopathogenesis, there are hereditary factors, irritant chronic conjunctivitis, tear film changes, vitamin A deficiency, race, eye color, ultraviolet rays, chronic micro trauma of the eye, and infections. In addition, lifestyle and environment also have an effect (sandy, dusty, hot climate and exposure to the midday sun because of outdoor work) $[1,2]$.

As the pterygium grows towards the center, surgery is often needed. Various forms of surgical treatment have been described and following almost all surgical treatments, patients may have various surgery-associated complaints (epithelial defect, sutures, etc.) during the healing process [3]. Various agents are used to reduce these complaints after surgery, the most widely used of which are artificial tears and autologous serum [4].

In recent years, several studies have shown that dexpanthenol, a panthenol-analogue, accelerates epithelial healing, as a precursor of co-enzymes that are a basic component of cellular metabolic processes [5]. The aim of the current study was to compare the effect of autologous serum and $5 \%$ dexpanthenol gel on postoperative patient comfort and the accelerating effect of the healing process.

\section{MATERIALS AND METHODS}

The study included 30 patients who were operated on by the same surgeon with a similar technique. None of the patients had any disease that would affect systemic and / or local wound healing. Approval for the study was granted by the Local Ethics Committee. In the study was adhered to the statement Helsinki. The surgical technique applied in all cases was pterygium resection with a crescent knife including the underlying Tenon's capsule, with insertion of autograft obtained from the upper bulbar conjunctiva, sutured by monofilament suture. The surgical suture was removed 7 days after surgery. The autologous serum was $50 \%$ tear diluted.

Patients were separated into two groups consecutively in this retrospective study. Written informed consents of the patients were obtained. Autologous serum was used in first operated cases (Group 1). Subsequently, \% 5 Dexpanthenol gel (2 times a day) was used in second operated group (Group 2). Both groups were administered post-operative Loteprednol etobonate $0.5 \%$ (one drop 4 times a day), Polyvinyl alcohol single dose eye drops (one drop 4 times a day), and $0.3 \%$ tobramycin eye ointment ( 2 times a day). All patients attended follow-up examinations on days 1, 3 and 7 postoperatively.

Patients who underwent surgery were questioned in respect of pain, stinging, watering, redness and graft edema. They were asked to define the characteristics of the pain, differentiating between irritation and stinging and between constant and intermittent striking pain. These 
questionnaires were completed by the patients' immediately after surgery and on postoperative days 1, 3 and 7. A Verbal Pain Scale (VPS) was used for pain; 0 (no pain VPS: 0), 1 (mild pain VPS:1-3), 2 (moderate pain VPS:4-6 ), 3 (severe pain VPS:7-9) and 4 (unbearable pain VPS:10). The stinging sensation was graded as five categories; 0 (no stinging), 1 (slight stinging sensation), 2 (intermittent stinging sensation), 3 (severe stinging sensation), and 4 (unbearable stinging sensation so that the eyelids could not be opened). Complaints of irritation were rated as 0 (no irritation), 1 (intermittent irritation), 2 (more than 10 irritations per day), 3 (irritation to wiping with continuous wipes). Findings of redness and graft edema were classified as 0 (none), 1 (mild), and 2 (extreme).

Patients with pterygium and a history of corneal disease, eye trauma or previous intraocular surgery, contact lens wearers, evidence of current intraocular inflammation on slit lamp examination and eyes with recurrent pterygium were excluded from the study. The size of the pterygium was measured as $2.1-4 \mathrm{~mm}$ from the limbus (horizontal length).

\section{Statistical Analysis}

All data were transferred to Excel and statistical analysis was performed using IBM SPSS for Windows version 22.0 software. Numerical variables were stated as mean \pm standard deviation (SD) and qualitative variables as number (n) and percentage (\%). When parametric test assumptions were met, the t-test was used in independent groups and the Mann Whitney U-test was used if there was no difference between the groups in terms of numerical variables. Evaluation of differences between the groups in terms of quality variables was examined using the Chi-square test. The Friedman test or the Cochran $\mathrm{Q}$ test was used to determine whether the severity of symptoms changed over time. A value of $p<0.05$ was accepted as statistically significant.

\section{RESULTS}

Group 1 comprised 4 (22.2\%) male and 14 (77.8\%) female patients with a mean age of $55.7 \pm 10.4$ years. Group 2 comprised $3(25 \%)$ male and 9 (75\%) female patients with a mean age of $49.3 \pm 12.0$ years $(p=0.139, p=0.131)$. There was no statistically significant difference between the groups at days 1,3 , and 7 in respect of pain, stinging and irritation complaints (Table 1). In Group 2, a statistically significant decrease was determined in these complaints on days 3 and 7 ( $p=0.002$, p0.001, $p=0.002$, respectively) (Table 1). There was no statistically significant difference between the groups on days 1, 3 and 7 in respect of redness (Group 1, $\mathrm{p}=0.006$, Group 2, $\mathrm{p}=0.001$ ) and graft edema (Group 1, $p=0.001$, Group 2, $p=0.001$ ). In both groups, there was a statistically significant increase in these findings on days 3 and 7 (Table 1). No complication related to surgery and drugs developed in any patient.

Table 1. Distribution of Symptoms and Signs

\begin{tabular}{|c|c|c|c|c|}
\hline Symptoms and Signs & Postoperative period & Group $1(n=18)$ & Group $2(n=12)$ & P Value between groups \\
\hline \multirow{4}{*}{ Pain distribution } & Day 1 & $0.89 \pm 0.90$ & $1.17 \pm 0.72$ & 0.249 \\
\hline & Day 3 & $0.89 \pm 0.58$ & $0.67 \pm 0.49$ & 0.415 \\
\hline & Day 7 & $0.50 \pm 0.71$ & $0.67 \pm 0.49$ & 0.368 \\
\hline & $P$ value in-group & 0.135 & $0.002^{*}$ & n.a. \\
\hline \multirow{4}{*}{ İrritation distribution } & Day 1 & $0.89 \pm 0.58$ & $1.33 \pm 0.49$ & 0.095 \\
\hline & Day 3 & $0.89 \pm 0.32$ & $0.67 \pm 0.49$ & 0.184 \\
\hline & Day 7 & $0.89 \pm 0.32$ & $0.67 \pm 0.49$ & 0.184 \\
\hline & $P$ value in-group & 1.000 & $<0.001^{*}$ & n.a. \\
\hline \multirow{4}{*}{ Stinging distribution } & Day 1 & $1.00 \pm 0.84$ & $1.00 \pm 0.85$ & 0.884 \\
\hline & Day 3 & $0.89 \pm 0.58$ & $0.50 \pm 0.52$ & 0.134 \\
\hline & Day 7 & $0.67 \pm 0.49$ & $0.50 \pm 0.52$ & 0.458 \\
\hline & $P$ value in-group & 0.449 & $0.002^{*}$ & n.a. \\
\hline \multirow{4}{*}{ Redness distribution } & Day 1 & $0.28 \pm 0.46$ & $0 \pm 0$ & 0.066 \\
\hline & Day 3 & $0.78 \pm 0.43$ & $0.67 \pm 0.49$ & 0.678 \\
\hline & Day 7 & $0.67 \pm 0.49$ & $0.83 \pm 0.39$ & 0.419 \\
\hline & $P$ value in-group & $0.006^{*}$ & $<0.001^{*}$ & n.a. \\
\hline \multirow{4}{*}{ Graft Edema distribution } & Day 1 & $0.06 \pm 0.24$ & $0 \pm 0$ & 1.000 \\
\hline & Day 3 & $0.89 \pm 0.58$ & $1.00 \pm 0.00$ & 0.632 \\
\hline & Day 7 & $0.83 \pm 0.62$ & $1.00 \pm 0.00$ & 0.465 \\
\hline & $P$ value in-group & $<0.001$ & $<0.001$ & n.a. \\
\hline
\end{tabular}

Pain distribution: 0 (VPS: 0), 1 (VPS:1-3), 2 (VPS:4-6), 3 (VPS:7-9), 4 (VPS:10), Irritation distribution : 0 (no irritation), 1 (intermittent irritation), 2 (more than 10 irritations per day), $\mathbf{3}$ (irritation to wiping with continuous wipes), Stinging distribution : $\mathbf{0}$ (no stinging), $\mathbf{1}$ (slight stinging sensation), $\mathbf{2}$ (intermittent stinging sensation), $\mathbf{3}$ (severe stinging sensation), $\mathbf{4}$ (unbearable stinging sensation so that the eyelids could not be opened), Graft edema and Redness distribution: $\mathbf{0}$ (none), $\mathbf{1}$ (mild), and $\mathbf{2}$ (extreme). 


\section{DISCUSSION}

Pterygium starts with complaints such as burning, stinging, irritation, hyperemia and the feeling of a foreign body in the eye from time to time. After moderate conjunctival and subconjunctival edema, a fibrous tissue is formed as a result of a micro ulcer caused by repair and scarification mechanisms, starting from the conjunctiva and extending towards the cornea [3]. Pterygium is usually asymptomatic and may cause sensations of burning, stinging, foreign body and photophobia. Progression to the visual axis or deterioration of the tear film layer may cause secondary astigmatism and decreased vision. Due to mechanical irritation, pterygium may be irritated and cause severe pain, stinging, watering problems in patients $[2,3]$.

Growth factors involved in the proliferation and differentiation of the corneal epithelium, such as vitamins and neuropeptides, are derived from the tears secreted from the lacrimal gland. They play an important role in wound healing [6]. Fox et al used autologous serum in Sjögren's syndrome for the first time in anterior segment eye disease [7]. A study by Kaya et al showed that autologous serum could be safely used in ocular surface problems due to various causes [8]. The mechanism of the healing effect of autologous serum is not yet fully understood, but growth factors and vitamins are thought to play a role. Most importantly, Epithelial Growth Factor is present in both serum and ophthalmic tears and has been found to be effective in the healing of traumatic epithelial abrasions [9]. Another substance that has been found to be effective in epithelization is fibronectin [10]. Serum concentration is an important factor in the efficacy of autologous serum and high concentrations of autologous serum have been found to be more effective [8].

Dexpanthenol (provitamin B5) occurs as a component of the analogous acid pantotene, which has an important role in the citric acid cycle of coenzymes [11]. It is a molecule necessary for proper structuring of the epithelial layer, which is an anti-inflammatory feature. In vitro experiments with dexpanthenol have demonstrated proliferation of human fibroblasts [12]. Raczynska et al. reported that using dexpanthenol gel in corneal and conjunctival injuries accelerated the wound healing process [13]. In a cohort study by Baumeister et al., post-PRK re-epithelialization and wound healing were observed to be faster in patients where dexpanthenol gel was used compared to those where it was not used [14].

In this study, the effects of autologous serum and dexpanthenol were investigated on wound healing and patient comfort in corneal and conjunctival wound healing. Patients in both groups were examined for complaints such as pain, stinging, irritation, redness and graft edema. The findings of the study suggested that each molecule is effective in patient comfort after anterior segment surgery. In the current study group using dexpanthenol there was found to be a statistically significant reduction in complaints of pain and irritation on days 3 and 7. Autologous serum may cause some problems in patient medication compliance due to weekly renewal and storage conditions. Therefore, dexpanthenol is a preferable agent because of the ease of patient accommodation and storage.

\section{Limitations}

Our study was performed in a relatively limited group. Our study should be supported by studies conducted with more patients. In our study, verbal scales were used for subjective symptoms. It was assumed that the patients gave accurate information. These are the main limitations of our study.

\section{CONCLUSIONS}

Many agents have been described to improve patient comfort after pterygium surgery. Of these, the most reliable and most investigated agent is autologous serum. The results of this study demonstrated that dexpanthenol is as effective and reliable a molecule after anterior segment surgery for patient comfort as autologous serum.

\section{DECLARATION OF CONFLICT OF INTEREST}

The authors received no financial support for the research and/or authorship of this article. There is no conflict of interest.

\section{REFERENCES}

1. Karukonda SR, Thompson HW, Beuerman RW, Lam DS, Wilson R, Chew SJ, Steinemann TL. Cell cycle kinetics in pterygium at three latitudes. Br J Ophthalmol. 1995; 79: 313-7.

2. Mackenzie FD, Hirst LW, Battistuta D, Green A. Risk analysis in the development of pterygia. Ophthalmol. 1992; 99: 1056-61.

3. Buratto L, Phillips RL, Carito G. Part A. Chapter 9. Symptoms. In: Buratto L, Phillips RL, Carito G, eds. Pterygium Surgery. Thorofare, NJ: SLACK Inc., 2000: 5-6. 
4. Sanchez-Avila RM, Merayo-Lloves J, Riestra AC, Berisa S, Lisa C, Sánchez JA, Muruzabal F, et al. Plasma rich in growth factors membrane as coadjuvant treatment in the surgery of ocular surface disorders. Medicine (Baltimore). 2018; 97: e0242.

5. Egger SF, Huber-Spitzy V, Alzner E, Scholda C, Vecsei VP. Corneal wound healing after superficial foreign body injury: vitamin A and dexpanthenol versus calf blood extract. Ophthalmologica 1999; 213: 246-9.

6. Scardovi C, De Felice GP, Gazzaniga A. epidermal growth factor in the topical treatment of traumatic corneal ulcers. Ophthalmologica. 1993; 206: 119-24.

7. Fox RI, Chan R, Michelson JB, Belmont JB, Michelson PE. Beneficial effect of artificial tears made with autologous serum in patients with keratoconjunctivitis sicca. Arthritis Rheum. 1984; 27: 459-61.

8. Kaya FS, Akova Y. The Effect of Autologous Serum Eye Drop Application on Epithelization in the Treatment of Various Ocular Surface Disorders and its Safety. Turk J Ophthalmol 2012; 42: 336-41.
9. Pastor JC, CalongeM. Epidermal growth factor and corneal wound healing: a multicenter study. Cornea. 1992; 11: 311-4.

10. Fredj-Reygrobellet D, Plouet J, Delayre T, Baudouin C, Bourret F, Lapalus P. Effects of aFGF and bFGF on wound healing in rabbit corneas. Curr Eye Res. 1987; 6: 1205-9.

11. Hanck AB, Goffin H. Dexpanthenol (Ro 01-4709) in the treatment of constipation. Acta Vitaminol Enzymol. 1982; 4: 87-97.

12. Christ T. Treatment of corneal erosion with a new ophthalmic gel containing panthenol. Spektrum der Augenheilkunde 1994; 8: 224-6.

13. Raczyńska K, Iwaszkiewicz-Bilikiewicz B, Stozkowska W, Sadlak-Nowicka J. Clinical evaluation of provitamin B5 drops and gel for postoperative treatmentof corneal and conjuctival injuries. Klin Oczna. 2003; 105: 175-8.

14. Baumeister M, Bühren J, Ohrloff C, Kohnen T. Corneal reepithelialization following phototherapeutic keratectomy for recurrent corneal erosion as in vivo model of epithelial wound healing. Ophthalmologica. 2009; 223: 414-8. 